\title{
MEMBACA PERSEPSI, MENAKAR PROSPEK: SEBUAH CATATAN REFLEKTIF TENTANG ULAMA DAN PEMBERDAYAAN PEREMPUAN DI LOMBOK
}

\author{
Fawaizul Umam
}

Dosen Filsafat Islam IAIN Mataram.

\begin{abstract}
Abstrak
In the growing debate on gender discourse, religious texts (normative doctrines) is one of primary bases of producing and reproducing theological arguments for the debate particularly on the issue of gender relation in society. Then, religious figures (Ulama) who pose the "authority" to interpret the text and to build social and religious assumptions (from the texts) on gender issues which influence the prospect and the feature of women empowerment in society become one influential factors for gender equality realization. Therefore, Ulama play significant role in determining social perception on gender in the religiouscultural level of society.
\end{abstract}

\section{A. Pendahuluan}

Belakangan studi-studi tentang perempuan kian marak. Fenomena itu perlahan menjadikan wacana gender menjadi icon tersendiri dalam kajian-kajian kebudayaan (cultural studies). Demikian juga dalam kajian-kajian keislaman (Islamic studies) kontemporer. Ada ghirah yang meluap-luap di sementara intelektual muslim untuk membongkar tradisi keilmuan klasik untuk kemudian merekonstruksi secara baru sejalan dengan spirit zaman yang terus berubah.

Dalam konteks wacana gender, domain keilmuan Islam klasik yang paling sering disoal karena kentalnya "anomali intelektual" di dalamnya adalah fiqh. Di kita, itu melahirkan greget penyusunan suatu fiqh "baru" yang belakangan kian serius menampilkan diri sebagai varian "baru" dari wacana fiqh dengan sebutan fiqh al-nisâ', fiqh (tentang) perempuan. Terlepas ketidakjelasan "jenis kelamin" (baca: epistemologi) fiqh al-nisâ' sebagai suatu disiplin, isu-isu seputar relasi 
gender yang digulirkan menggugah beragam respons kritis (juga emosional!). Cuma sayang, respons yang bermunculan di dalam dan di sekitar wacana tersebut umumnya masih berkutat-berputar di sekitar pembongkaran kritis atas teks-teks ajaran.

\section{B. Pembahasan}

Tulisan ini sendiri adalah salah satu bentuk respons intelektual itu, tapi dengan line bahas berbeda. Bukan terutama melakukan kritik teks atas ajaran, tapi lebih pada menyisir beroperasinya teks-teks ajaran berikut segala bentuk tafsirnya dalam pikiran para tokoh agama, ulama. Ini penting, mengingat peran mereka amatlah determinan dalam setiap proses reproduksi pengetahuan keagamaan masyarakat. Terlebih dalam struktur masyarakat tradisional paternalistik, peran eksistensial mereka hingga tingkat tertentu sangat menentukan setiap gerak dinamika perubahan sosial. Maka bisa dibayangkan apa kira-kira yang bersemayam dalam kesadaran gender masyarakat bila ternyata, misalnya, asumsiasumsi keagamaan yang terus-menerus direproduksi ulama cenderung misoginis, bias gender, dan mendiskriminasi perempuan. Dari situ, kita layak bertanya seberapa cerah prospek pemberdayaan perempuan di kini dan mendatang. Itu pertanyaan menarik yang relevan dikedepankan sehubungan peran sosial signifikan ulama di satu sisi dan persepsi mereka seputar relasi gender di sisi lain.

Paling-tidak dua tanya menarik itulah yang coba penulis cari jawabnya lewat sebuah penelitian tentang persepsi gender ulama Lombok. ${ }^{1}$ Sejauh ini wacana

\footnotetext{
${ }^{1}$ Penelitian dimaksud berpendekatan kualitatif dengan feminisme sebagai kerangka umumnya, yakni pengenaan kategori gender sebagai aspek analisis utama terhadap seluruh data yang kemudian diturunkan secara kritis-deskriptif. Para tuan guru yang dipilih secara purposif didudukkan sebagai subjek penelitian dan persepsi mereka tentang relasi gender sebagai unit of analysis yang digali lewat wawancara pola campuran dengan kategori depth interview. Untuk
} 
perempuan di pulau Lombok relatif berlangsung massif melalui aneka praktik diskursif, mencakup berbagai proses transmisi kesadaran publik, seperti pendidikan, pelatihan, pengajian, tabligh, khutbah, penerbitan, penyiaran, dan sejenisnya, termasuk proses-proses pembuatan kebijakan publik terkait. Melalui itu semua, aneka konstruk kesadaran gender diciptakan dan dilanggengkan dan dipertarungkan di tengah masyarakat Sasak, etnis mayoritas (asli) di Lombok, yang religius. Salah satu pihak yang mengambil peran (ter-) penting dan menentukan dari keseluruhan proses dimaksud adalah tokoh agama, para ulama, yang untuk konteks Lombok hormat disapa sebagai tuan guru (kyai di Jawa atau ajengan di Sunda).

Mengapa tuan guru? Di sinilah sisi menarik, terutama karena untuk konteks masyarakat Sasak Lombok yang relatif masih berstruktur budaya paternalistik dan patriarkhis peran tuan guru sangat signifikan sekaligus menentukan konstruk kesadaran kolektif masyarakat dan struktur realitas sosial-keagamaan. Tersebab itu, konstruksi epistemologis apapun yang dibangun para tuan guru dalam banyak hal ditengara kuat memberi impact bagi bentuk-pola kesadaran keagamaan dan weltanschauung masyarakat, tak terkecuali pemahaman gender. Itulah mengapa, penting menelusuri persepsi tuan guru seputar isu-isu relasi gender dalam konteks pemberdayaan perempuan di Lombok, terutama untuk pemetaan (mapping) lebih lanjut apakah bangun-gagasan mereka itu bersifat produktif atau justru kontrapoduktif bagi persebaran nilai-nilai sadar gender di tengah masyarakat Sasak dan rekonstruksi kesadaran mereka tentang peran gender (gender roles). Diharapkan, dengan itu, dapat diketahui problem-problem dasar kulturalmetode dokumentasi. 
keagamaan sekaligus disusun penyikapan solutifnya dalam kerangka pemberdayaan perempuan sehingga prospeknya pun ke depan dapat diraba.

Sehubungan itu, masalah terpokok yang hendak disisir penelitian tersebut adalah bagaimana persepsi tuan guru seputar relasi gender. Pencarian jawabnya meniscayakan perlunya memperhatikan faktor-faktor yang secara hermeneutis melatari persepsi tuan guru itu guna melihat bagan epistemologis yang mengerangkainya. ${ }^{2}$ Kemudian, dengan pengenaan perspektif gender, beragam persepsi tersebut didekati terutama untuk menemukan nilai etik-aksiologisnya dalam konteks pemberdayaan perempuan di tengah masyarakat Lombok.

Lalu, bagaimana hasilnya? Sungguh tak mengagetkan.

\section{b.1. Epistemologi Persepsi}

Secara hermeneutis, berdasar hasil analisis atas data, dijumpai adanya kelindan erat antara persepsi gender tuan guru dan latar weltanschauung mereka. Latar dimaksud menunjuk pada prasangka, keterkondisian historis (historical situatednes), dan latar tradisi mereka. Secara langsung maupun tidak, anasir hermeneutis itu membangun dan mewarnai horison tuan guru dalam menderivasi segenap pesan tekstual ajaran Islam seputar relasi gender. Jadi jelas, persepsi para tuan guru itu tidaklah berawal dari kekosongan, tidak berada dalam situasi vakum budaya. Ia muncul sebagai refleksi langsung dari gugusan pengalaman panjang pengetahuan dan kehidupan mereka.

\footnotetext{
${ }^{2}$ Faktor-faktor tersebut menunjuk pada prasangka, keterkondisian historis, dan latar tradisi tuan guru yang dalam hal ini dihimpun dari biografi hidup dan intelektual mereka. Secara hermeneutis, semua faktor itu membangun horison tuan guru dalam menderivasi segenap pesan teks-teks ajaran Islam tentang perempuan dan membentuk corak persepsi mereka. Penelisikan dijalankan dengan mengikuti pesan ontologis-hermeneutis Hans Georg Gadamer-sebagaimana diungkap Richard E. Palmer, Hermeneutics: Interpretation Theory in Schleiermacher, Dilthey, Heidegger, and Gadamer, Evanston: Northwestern University Press, 1969, 33, 42.; Richard King, Agama, Orientalisme, dan Poskolonialisme, terj. Agung Prihantoro, Jogjakarta: Qalam, 2001, 138, 143.; dan Gadamer sendiri, Truth and Method, London: Sheed and Ward, 1975, 264.
} 
Tersebab itulah penyisiran faktor-faktor hermeneutis itu penting. Dimulai dengan meletakkan segenap persepsi tuan guru itu sebagai unit analisis utama untuk kemudian dibaca dengan analisis wacana kritis (critical discourse analysis). ${ }^{3}$ Pengunaan teknik analisis ini berkait rapat dengan dipilihnya analisis gender (gender analysis) sebagai cara umum penghampiran. Penting, terutama untuk menyingkap proses produksi, struktur internal, dan seluruh bentuk pendisiplinan yang inheren dalam "teks" (pembicaraan/persepsi) tuan guru (yang didapat via interview) seputar masalah relasi gender. Lalu untuk melihat eksistensi persepsi itu sendiri sebagai suatu "rezim pengetahuan" dalam konteks pemberdayaan perempuan pada masyarakat Sasak dilakukan suatu tilikan kritis atasnya dengan pelibatan perspektif feminisme-sekedar semacam entry ke arah bagaimana kira-kira prospek pemberdayaan (empowerment) perempuan di Lombok ke depan.

Penerapan analisis wacana kritis mengantar kita pada kesadaran awal tentang eksistensi tuan guru itu sendiri di tengah konteks sosial masyarakatnya. Sebagai aktor sosial yang mendiami entitas wacana sosial yang khas, tradisionalpaternalistik, mereka cenderung menjadi penentu arah dinamika sosial. Sebab itu, terlepas variabilitas modus eksistensial masing-masing, pengetengahan mereka sebagai informan mau tak mau menuntut penghirauan akan kontrol wacana yang beroperasi dalam pikiran (mind) dan prilaku (act) mereka.

Menyelami persepsi gender mereka dengan demikian tak hanya akan bersentuhan dengan sekian standardisasi kesetaraan dan/atau ketimpangan gender,

\footnotetext{
${ }^{3}$ Untuk ulasan pengantar tentangnya, lihat Teun Adrianus van Dijk, "Editor's Forward to Critical Discourse Analysis," dalam Discourse and Society, vol. 4, no. 2, 1993, 131-2. dan Ibid., "Principles of Critical Discourse Analysis," dalam Discourse and Society, vol. 4, no. 2, 1993, 24983.; bdk., Gunther Kress, "Critical Discourse Analysis," dalam Annual Review of Applied Linguistics, no. 11, 1991, 84-99.
} 
tapi berurusan pula dengan beberapa hal yang secara epistemologis mengerangkai seluruh bangunan persepsi mereka, yakni: (1)tekstualitas, (2)mistifikasi, (3)kuasa wacana, dan (4)mental-models.

Pertama, Tekstualitas. Seperti lazimnya ulama, persepsi tuan guru (informan) mengenai relasi gender secara langsung berkait rekat dengan teks-teks doktrinal Islam yang (tafsirnya) cenderung "membenci perempuan" (misoginis). Itu tidak hanya karena Islam lahir di tengah masyarakat bertradisi "lelaki is the best and the first", melainkan juga berlangsungnya kesimpangsiuran dalam memahami otoritas teks di satu pihak dan dimensi penafsiran di pihak lain yang acap bermuara pada reproduksi wacana yang bertentangan dengan nilai kesetaraan gender yang sejatinya substantively diusung Islam sendiri. Agaknya itu memang konsekuensi logis dari betapa di dalam tradisi Islam otoritas teks lebih kerap dimenangkan demi memelihara idealitas Islam sebagai agama samawi. Trend paradigmatik "mensubordinasi konteks atas teks" menjadi fenomena umum dalam nyaris keseluruhan dinamika keilmuan Islam sejak pascaabad pertengahan Hijriyah. Imbas lanjutnya, banyak ajaran Islam sering kehilangan konteks (sekaligus relevansi) sosialnya.

Demikian juga diskursus gender dalam Islam acapkali menemui jalan buntu karena kemapanan otoritas tafsir yang cenderung ahistoris itu. Menariknya, oleh tuan guru, itu justru dilembagakan sedemikian rupa ke dalam kognisi dan kesadaran umat melalui, antara lain (yang paling lazim), institusi pendidikan (pesantren), even-even pengajian, khutbah Jumat, dan momen-momen pembelajaran lainnya. Disadari atau tidak, pelembagaan anasir tekstualitas melalui proses-proses transmisi pengetahuan itu turut memperefektif proses reproduksi 
kemapanan teks dalam kognisi dan kesadaran umat (santri dan masyarakat). Tekstualitas dengan demikian menjadi variabel penting dalam struktur epistemologi pengetahuan tuan guru.

Tekstualitas, pembacaan tekstual atas teks ajaran, secara penuh dapat ditelusuri dalam persepsi tuan guru. Taruhlah tentang klaim "superioritas laki atas inferioritas perempuan" yang umumnya mereka (seperti juga para ulama klasik) landaskan pada Qs. al-Nisâ' (4): 34. Sebagian besar informan memang berpandangan bahwa nash tentang "kepemimpinan laki-laki atas perempuan" tersebut memang sudah tuntas, qath $\hat{\imath}$. Secara tekstual laki-laki memang dipilih Tuhan untuk jadi pemimpin, demikian keyakinan mereka. Fakta itu menggambarkan betapa otoritas teks agaknya masih menjadi kekuatan suprematif dalam membentuk pengetahuan gender mereka. Tengok misal pandangan TGH Lalu Muhammad Turmuzi Badarudin tentang pola pembagian waris 2:1 bagi lelaki dan perempuan. Menurutnya, aturan Qs. al-Nisâ' (4): 11 tentang pola pembagian waris sedemikian itu sudah qath $\hat{\imath}$, final, tidak dapat dan tidak boleh ditafsirkan lain. Begitu pula tentang kemungkinan penyetaraan nilai kesaksian seorang lelaki sama dengan seorang perempuan baik dalam kasus mu'amalah (perdata) maupun jinâyah (pidana) ditolaknya. Sebab, baginya, penetapan Qs. alBaqarah (2): 282 soal nilai kesaksian satu lelaki setara dengan kesaksian dua orang perempuan itu, sekali lagi, sudah qath $\hat{\imath}$.

Dengan reasoning senafas, TGH Muharrar Mahfuzh, juga bertindak mengunci pintu penalaran-karena itu nash (!)—dan kepatuhan terhadap pesan-pesan tekstualnya diringkasnya sebagai keharusan ta'abbudî. Simak tuturnya tentang ayat "kesaksian" itu: 
“... Adapun pandangan (bahwa) perempuan memiliki kelemahan itu saya kira suatu yang sifatnya analisa, tapi hakikatnya adalah ketentuan Allah. Nah, kalau saya memahami bukan karena Islam menempatkan perempuan dalam posisi yang lebih rendah, tapi memang karena Allah yang menentukan seperti itu. Janganlah itu dilihat sebagai ketidakadilan Tuhan kepada perempuan..."

Mensimplifikasi suatu kenyataan hasil konstruksi sosial sebagai kodrat (ketentuan) Allah secara tidak langsung berarti menutup kans mendekati nash secara kemanusiaan (antroposentris), berdasar kepentingan manusia. Frase itu jelas berniat "melarikan" persoalan ke Tuhan. Apa yang sesungguhya belaka sebuah penafsiran lalu secara tak langsung distempel atas nama Tuhan. Pun alasan "kelemahan perempuan sebagai ketentuan Allah" sesungguhnya menggiring pada keruntuhan klaim-klaim universalitas pesan al-Qur'an sendiri, seperti keadilan (al-'adâlah), egaliterianisme (al-musâwah), dan kebebasan (al-hurriyah). Gaya macam itu, mengutip Arkoun, berpotensi menggelincirkan geliat pemikiran keislaman ke kubangan logosentrisme. ${ }^{4}$ Dan itulah memang yang telah terjadi. Trend logosentrisme dalam Islamic studies mutakhir sejauh ini telah menyebabkan kajian-kajian keislaman, doktrin dan sejarahnya, mandul dan tidak produktif.

Kecenderungan itulah yang tampaknya juga menghinggapi benak-pikir TGH Musthafa Umar ketika dimintai komentar soal nuansa diskriminatif gender pada pembagian waris-nuansa yang seketika ia tampik:

\footnotetext{
${ }^{4}$ Di antara ciri utama pemikiran logosentris, selain kecenderungannya mendasarkan diri pada satu 'ashl yang dipancang sebagai kriteria tunggal validitas kebenaran, juga mengalihkan realitas menjadi sebatas retorika, permainan bahasa dan kata-kata. Realitas masa lalu Islam melalui masa "formatifnya" sebagai agama tak lagi diperlakukan sebagai deretan fakta yang terikat oleh ruang dan waktu, tapi sebagai fiksi yang mengatasi kedua dimensi itu. Akibatnya seluruh ajaran Islam kehilangan dimensi historisitasnya. Lihat Mohammed Arkoun, "Logocentrisme et Vérité Religieuse dans la Pensée Islamique,” dalam Studia Islamica, 35, 1972, 5-51.
} 
“... Itu karena lelaki mempunyai tanggungjawab mencari nafkah... Dari sinilah Islam menetapkan... Kita tidak boleh mengubahnya, meski sekarang keadaannya lain. Di sini ada nash yang tidak boleh di-qiyâs-kan, la qiyâsa mâ wujûdihâ. Jangan kita meng-qiyâs masalah waris sebab nash sudah ada, dan lelaki mendapat warisan lebih banyak sebab bebannya ada dan ada hikmahhikmah lain yang dirahasiakan Allah. Karena hukum nash itu (Qs. al-Nisâ' [4]: 11) qath iyah, maka tidak boleh diijtihadkan. Dan itu tetap berlaku universal, sampai kapanpun..."

Praktis, dengan ungkapan "tidak boleh mengubahnya meski sekarang keadaannya lain", sesungguhnya dia tengah menunjukkan pola tekstualitas dalam membaca teks dan menghampiri konteks. Pembacaan tekstual tentu tidak welcomed terhadap probabilitas tafsir atas nash sekaitan disparitas ruang, waktu, dan situasi. Jadinya hitam-putih dalam melihat kenyataan, dan pernyataan bahwa tekstual nash "tetap berlaku universal, sampai kapanpun", merupakan konsekuensi logisnya. Dengan kerangka pikir berparadigma "pokoknya" itu pula TGH Musthafa Umar cenderung menolak kepemimpian perempuan di bidang sosial-politik dan secara tidak langsung melakukan domestikasi perempuan, menggiring mereka ke sektor "rumahan".

Beberapa ujaran di atas pada prinsipnya merupakan representasi dari cara pandang dan persepsi rata-rata semua informan. Bahkan boleh jadi itu "prototipe" cara pandang dan persepsi para tuan guru di Lombok-mengingat para informan adalah sosok tuan guru yang bisa dibilang paling berpengaruh di pulau itu. Seluruh apa yang ditunjukkan semua informan, secara umum menunjukkan totalitas kesadaran subjek yang diikatkan pada teks (Qur'an maupun hadits) dan 
otoritas tafsir. Informan, dalam banyak hal, erat memegangi dan tak bergeser sedikitpun dari bunyi teks dan deretan diktum dan/atau qawl hukum yang terjabar di kitab-kitab kuning, misalnya tentang formulasi qath 'î dan zhannî. Nash dan otoritas tafsir dalam pada itu menjadi begitu tak terbantahkan dan menempati posisi superior dalam otak informan.

Selanjutnya, rangkaian teks dan otoritas penafsiran (baca: tekstualitas) itu menjelma menjadi semacam jaringan kuasa kontrol wacana pengetahuan yang saling menguatkan dalam mendikte dan mengendalikan persepsi informan. Tekstual, begitulah. Subjek dalam pada itu tenggelam di dalam teks, dan karenanya kecenderungan untuk mensubordinasi perempuan ke bawah laki-laki menjadi bagian integral dalam memanggul keabsahan teks.

Kedua, Mistifikasi. Tekstualitas juga mendorong lahirnya mistifikasi. ${ }^{5}$ Sebab, otoritas teks yang sering direproduksi tanpa rasionalisasi berdasar nalar historis berpeluang menjadi dominan. Di situ mitos pun lebih terkukuhkan tinimbang kebenaran. Fakta itu bisa dijumpai dari banyak asumsi doktrin Islam mengenai soal gender yang relatif tidak beranjak dari anasir "medieval" masyarakat (Arab) Timur Tengah abad pertengahan Hijriyah. Asumsi-asumsi doktrinal itulah yang membebat pola pikir para tuan guru (informan). Tak ayal, persepsi gender yang mereka bangun pun tak jauh beda dengan trend pemikiran Islam klasik yang terjejali aneka mitologi. Wujudnya adalah mistifikasi berpikir. Banyak

\footnotetext{
${ }^{5}$ Mengikuti pemerian Arkoun, mistifikasi adalah penggunaan mitos secara bertentangan dengan fungsi dan arti yang sebenarnya, yakni sebagai himpunan norma yang membenarkan keadaan sosial dan politis tertentu. Mohammed Arkoun, Nalar Islami dan Nalar Modern: Berbagai Tantangan dan Jalan Baru, ab. Rahayu S. Hidayat. Jakarta: INIS, 1994, 313.
} 
argumentasi gender dalam Islam yang dikukuhkan bersandar kepada beragam mistifikasi itu ketimbang rasionalisasi atau empirisisasi faktual.

Dengan mistifikasi, otoritas teks diganti dengan otoritas mitos. Dalam banyak hal, otoritas mitos itu ternyata memiliki kemampuan kontrol pikiran yang luar biasa mencekam; seseorang tak butuh rasionalisasi apapun atas persoalan yang secara a priori telah diyakini kebenarannya. Dalam konteks wacana gender Islam, mitos itu menjadi variabel masalah yang justru sangat dipercaya kebenarannya kendati tidak punya otoritas sumber teks yang jelas. ${ }^{6}$

Rata-rata persepsi para informan merangkul mistifikasi itu. Taruh misal, TGH Sibawaih. Ketika ditanya apakah perempuan boleh memegang kepemimpinan di bidang sosial-politik, tokoh pendiri sebuah pamswakarsa besar di Lombok ini menjawab tegas tidak boleh: "Ah, itu (perempuan memegang kepemimpinan politik, pen.) kurang tepat. Tidak boleh, karena akal perempuan itu terbatas...."

Mistifikasinya berlanjut ke soal kemungkinan menyetarakan nilai kesaksian perempuan sama dengan kesaksian laki-laki oleh sebab perkembangan konteks ruang dan waktu-yang karenanya secara tekstual bertentangan dengan penegasan eksplisit Qs. al-Baqarah [2]: 282). “Tidak boleh,” tukasnya. "Sebabnya satu, orang perempuan pendiriannya lemah, kalau orang laki-laki pendiriannya kuat dan tegas...." Atas dasar "kenyataan" itu semua, ia pun bersimpulan bahwa Islam

\footnotetext{
${ }^{6}$ Misalnya, soal keyakinan dogmatik tentang penciptaan Hawa dari tulang rusuk Adam. Di antara sekian ayat yang menyinggung seputar asal-mula kejadian manusia, Qs. al-Nisâ' (4): 1 adalah rujukan utama. Dengan ayat tersebut, para ulama beranggapan bahwa Adam adalah manusia pertama yang dengan tulang rusuknya Hawa diciptakan. Karena itu, secara material, perempuan dipandang subordinat dari laki-laki. Sebenarnya anggapan bahwa nafs wâhidah itu laki-laki (Adam) adalah mistifikasi tanpa dasar otoritatif. Tak ada penjelasan pasti-tegas tentang itu, kecuali beberapa hadits kontroversial yang diragukan validitasnya karena kuat disinyalir bersumberkan kitab suci sebelumnya. Rasyîd Ridlâ adalah salah satu yang mensinyalir demikian. Dalam Tafsîr al-Manârnya, sebagaiman dikutip Nasaruddin, ia menandaskan: "Seandainya tidak tercantum kisah kejadian Adam dan Hawa dalam Kitab Perjanjian Lama (Kejadian 2:21), niscaya pendapat yang keliru (itu) tidak pernah terlintas dalam benak seorang muslim." Lihat Nasaruddin Umar, "Perspektif gender dalam Islam,” Jurnal Paramadina, I/1, Juli-Desember, 1998, 96-128.
} 
memang cenderung lebih mengunggulkan lelaki daripada perempuan. Dan itu karena akalnya. Simak ungkapannya berikut yang ia klaim berdasar sebuah hadits $^{7}$ :

“...Akal laki-laki 9, akal perempuan 1. Sebaliknya, syahwat perempuan 9 dan syahwat laki-laki justru 1. Karena itulah kecintaan perempuan terhadap keduniaan lebih tinggi karena syahwatnya lebih banyak... Kenapa? Karena memang kodratnya perempuan itu lemah!"

Luar biasa. Mistifikasi tak berbeda juga dilakukan TGH Mustiadi Abhar, ketika ditanyakan betulkah Islam memang lebih mengunggulkan kaum lelaki:

"Memang laki-laki itu dominan. Mereka memang lebih diunggulkan. Banyak dominan laki-laki, iya kan? Karena bila dilihat dari segi takdirnya, perempuan memang dibuat (Allah) lebih lemah daripada laki-laki... Laki-laki diberi akal 9, sedang perempuan cuma satu. Sehingga hal-hal yang berkaitan dengan (urusan) negara memang lebih dominan laki-laki. Itu terkait dengan asal kejadian keduanya..."

Setali tiga uang, nuansa mistifikasi itu juga menjelma pada TGH M. Najmuddin Ma'mun. Simak komentarnya soal kesaksian dua perempuan sebanding dengan seorang lelaki, terkhusus pada mistifikasinya tentang

\footnotetext{
${ }^{7}$ Tak jelas hadits yang mana. Namun, kemungkinan besar mistifikasi itu bertitik anjak dari hadits "nâqishât 'aql wa dîn" yang secara tekstual-eksplisit mengungkap keunggulan kualitas lelaki atas perempuan. Hadits ini, uniknya, memang shahîh $\underline{h}$ - termuat di shahîh hayn. Lihat Imâm al-Bukhârî, "Kitâb al-Haidl - Bâb Tark al-Haa'idl al-Shaum," dalam Shahhîh al-Bukhârî, Juz I, Hadits ke-298 (Beirut: Dâr Ibn Katsir al-Yamâmah, t.th.), 116; dan Imâm Muslim, "Kitâb al-Îmân - Bâb Nuqshân al-Îmân bi Naqsh al-Tha'at," dalam Shahîh Muslim, Juz I, Hadits ke-132, Beirut: Dâr alFikr, 1992, 55-6. Menurut Masdar, status hadits tersebut bukan mutawatir dan bukan pula masyhur, sedang di kalangan muhadditsin sendiri hadits tersebut berstatus zhannî. Masdar F. Mas'udi, Islam dan Hak-hak Reproduksi Perempuan. Bandung: Mizan, 1997, 160-1. Sementara bagi Engineer, hadits tersebut tertolak sebagai hujjah karena irasional dan berlawananan dengan pesan egalitarianisme al-Qur'an. Bahkan Prof. Abdul Hamid, sebagaimana dikutipnya, menganggapnya sebagai hadits palsu. Lihat Asghar Ali Engineer, Hak-hak Perempuan dalam Islam, terj. Farid Wajidi dan Cici Farkha Assegaf. Jogjakarta: LSPAA-Yayasan Prakarsa, 1994, 112.
} 
“gangguan kejiwaan pada perempuan menjelang menstruasi”-yang jelas-jelas sudah terpatahkan dalam kajian-kajian psikologi (dan medika) ${ }^{8}$ mutakhir:

“Oh, kalau itu qath 'î. Dalam al-Qur’an jelas-jelas itu! Kenapa kesaksian tidak diperbolehkan (1 perempuan setara 1 lelaki, pen.)? Karena perempuan itu emosional! Sedang dalam keadaan menjelang mens (-truasi) saja mereka mengalami gangguan kejiwaan, berubah perasaannya, sehingga dikhawatirkan kesaksiannya nanti merugikan terdakwa. Anda sudah nikah belum? Bila belum, Anda tidak tahu bagaimana jiwa perempuan. Anda tidak tahu kenapa dia marah-marah tanpa jluntrung menjelang mens...."

Kemudian ketiga, Kuasa Wacana. Kedua "variable" di atas dalam perjalanannya kemudian menjadi kuasa pengetahuan yang secara laten selalu mencari ruang kosong dalam pikiran para tuan guru (informan). Khazanah Islam klasik yang diakrabi dalam banyak hal diasumsikan telah mencipta kuasa wacana sedemikian rupa yang hingga taraf tertentu menjadi kontrol atas pikiran dan prilaku mereka.

Sejauh menunjuk khazanah keilmuan klasik mengenai relasi gender, kontrol kuasa wacana itu dikendalikan oleh wacana "misoginis" yang terus-menerus direproduksi oleh keseragaman tafsir dan mistifikasi yang menghuni kognisi tuan guru sebagai person maupun anggota komunitas. Di tingkat sosial, dengan logika kuasa wacana tersebut, mereka tak pelak terdorong untuk memfungsikan dirinya sebagai apparatus kekuasaan wacana keagamaan dominan. Bisalah lalu dibayangkan kuasa wacana macam apa yang mengontrol geliat pikir dan prilaku

\footnotetext{
${ }^{8}$ Lihat argumentasi juga perdebatannya di Jalaluddin Rahmat, "Dari Psikologi Androsentris ke Psikologi Feminis: Membongkar Mitos-mitos tentang Perempuan," Jurnal Ulumul Qur'an, Edisi Khusus, V/5\&6 ,1994, 12-28.
} 
tuan guru bila wacana perempuan yang direproduksi secara terus-menerus oleh khazanah teks-teks klasik itu adalah wacana yang "misoginis".

Hampir secara keseluruhan, wacana keilmuan Islam klasik itu tampil hegemonik menguasai pengetahuan dan kesadaran (gender) tuan guru. Aneka varian pengetahuan yang dilansir para ulama tempo doeloe cenderung diperlakukan sebagai kebenaran final dan karena itu menutup kemungkinan alternatif. Simak, misalnya, gaya "pendalilan” TGH Muhammad Zainul Majdi ketika menyikapi soal pola-bagi kewarisan Islam yang oleh kalangan feminis sering dianggap diskriminatif gender secara tekstual:

"Kalau menurut saya, sudah banyak dijelaskan dalam kitab-kitab al-Shabuni (italic dari pen.) atau segala macam itu bahwa sesungguhnya dua berbanding satu untuk laki-laki itu pada akhirnya membawa kemaslahatan pada wanita itu sendiri..."

Dalam hal itu, ketokohan seorang al-Shabuni seolah dijadikan pengabsah, garansi, bagi finalitas kebenaran tentang pola pembagian waris dimaksud. Secara tidak langsung, seolah menegaskan bahwa persoalan selesai karena al-Shabuni seorang ulama besar. Kecenderungan itu juga terulang kala pimpinan Nahdlatul Wathan (NW) ini mempersepsi discourse kepemimpinan perempuan di bidang sosial-politik:

"Kalau kepemimpinan dalam arti umum, misalnya sebagai anggota legislatif, kemudian hal-hal yang diputuskan secara kolektif, saya pikir tidak masalah. Yang dipermasalahkan adalah bila kepemimpinannya itu dalam artian dia memiliki kekuasaan tinggi dalam suatu negara. Bagi kita yang bermadzhab Syâfi î̀ (italic dari pen.) dan kita yakini itu, ya memang tidak dibolehkan 
perempuan memimpin... (itu) bukan berarti pengekangan terhadap aktualisasi wanita dalam arti wanita tidak boleh dalam ranah publik, tetapi sekali lagi itu bermaksud ingin memberi keseimbangan. Jadi tidak bolehnya itu apabila dia menjadi pemimpin negara, atau (memimpin) di suatu organisasi kemasyarakatan seperti Nahdlatul Wathan yang bermadzhab Syâfi'î ini...”

Sekedar menunjuk, kuatnya kontrol wacana itu juga menampak pada sikappikir TGH Achmad Fadly Fadlil Thahir saat diminta pandangannya seputar kepemimpinan sosial-politik perempuan. Serta-merta ia menolak dengan alasan pendapat al-Mawardi tentang tujuh syarat mu'tabarah dalam hal ahl al-imâmah. Dengan tangkas alumnus Shaulatiyah Makkah ini mengambil-oper pandangan Imam al-Mawardi sebagaimana termaktub dalam magnum opus-nya, Al-Ahkâm al-Sulthâniyah wa al-Wilâyât al-Dîniyyah. "Syarat untuk menjadi pemimpin publik atau politik, yang pertama adalah keadilan. Di sini, adilnya wanita itu agak sulit karena faktor sensitif, mereka perasa...," ujarnya.

Demikianlah rangkaian sumber-sumber klasik itu cenderung di-copy-paste oleh para informan dalam menelaah aneka persoalan peran gender. Nyaris tidak ada perbedaan dengan pengetahuan dasar yang direproduksi dalam banyak kitab klasik. Hampir tidak ada alternatif lain dalam pikiran sebagian besar informan kecuali dengan mematok harga mati ketentuan kitab kuning sebagai sebuah kebenaran normatif, bahkan hingga ke persepsi redaksional pun tidak menunjukkan distingsi. Dengan kontrol wacana sedemikian, sejalan dengan fungsi sosialnya, tuan guru tampil mengedepan menjadi apparatus hegemoni wacana tertentu di tengah masyarakat. 
Dan terakhir, keempat, Mental-Models. Istilah ini sering disemaknakan sebagai store (toko) yang ada dalam kognisi dan kesadaran person (informan; tuan guru). Dengan lain kata, ia adalah serangkaian pengalaman dan gugusan pengetahuan yang mengendalikan pikiran seseorang. ${ }^{9}$ Guna membangun analisis tuntas atas proses kompleks terkait bagaimana kuasa wacana mengontrol pikiran seseorang, bisa disisir melalui mental-models itu. Dalam konteks penelitian ini mental-models informan dapat dieja sebagai akumulasi pengalaman dan pengetahuan tentang relasi gender dari deretan panjang kontrol wacana yang beroperasi dalam kognisi mereka. Mental-models mereka bertolak dari pola yang sama dan dengan stereo-type yang sama pula.

Kecenderungan sedemikian lahir bukan belaka karena mereka berjenis kelamin laki-laki, tetapi lebih jauh karena ajuan perspektif mereka muncul dari model mental yang bias laki-laki (male-biased). Artinya, sudut tilikan yang mereka gunakan adalah "pengalaman laki-laki". Tak pelak, wacana "laki-laki" otomatis menjadi tolok ukur penilaian atas segenap isu relasi gender. Maka, tak aneh bila penafsiran mereka terhadap teks-teks ajaran Islam juga terhadap khazanah Islam klasik yang menyoal topik terkait cenderung menguntungkan laki-laki. Terlebih jika dirunut ke belakang, diskursus fiqh-kemana para tuan guru terutama menumpukan mentalitas pikirnya-memang sebuah wacana yang tak lebih tak kurang bersifat patriarkhis ( $\underline{h} u k m$ al-ab̂) .

\footnotetext{
${ }^{9}$ Pengertiannya di sini mengacu pada Senge yang ia definisikan sebagai “....deeply held internal images of how the world works, images that limit us to familiar ways of thinking and acting. Very often, we are not consciously aware of our mental models or the effects they have on our behavior." Peter M. Senge, The Fifth Discipline: The Art and Practice of the Learning Organization, New York: Doubleday Currency, 1990, 8.
} 


\section{b.2. Mempersepsi Relasi Gender}

Demikianlah, gugusan persepsi mereka memang cenderung setarikan nafas dengan trend umum intelektualisme keislaman klasik yang sejauh ini memang mendominasi cara pandang keagamaan kaum muslim umumnya. Selain itu juga merepresentasikan kecenderungan umum kebanyakan ulama. Suatu trend pikir yang tekstual, kental oleh mistifikasi, terikat dengan bayang-bayang kuasa wacana yang terbakukan sejak pasca-abad pertengahan Hijriyah (sejak "pintu ijtihad ditutup"), yang kesemuanya bila dirunut berkait-rapat dengan mental-models mereka sendiri. Ini fakta memang tak mengejutkan; di dalam dugaan. Simpulan epistemologis atas struktur pengetahuan persepsional tuan guru itu sendiri disandarkan pada persepsi mereka seputar relasi gender, yakni: (1)pembagian peran, (2)kepemimpinan sosial-politik, (3)kesaksian, (4)pembagian waris, dan (5)poligami.

Soal pembagian peran gender, secara umum, para tuan guru (informan) cenderung mensubordinasi peran perempuan atas laki-laki. Berlandas sekian asumsi keagamaan yang dalam perspektif gender terkategori misoginis, mereka menggariskan pembagian peran antarkeduanya dengan mendomestikasi peran perempuan dan sebaliknya bagi lelaki hingga berujung pada pemilahan lazim peran domestik dengan publik. Hampir seragam mereka memilah peran eksistensial lelaki pada ruang publik (al-wilâyat al-'âmmah) dan perempuan di ranah domestik (al-wilâyat al-khâshshah). Beberapa informan memang membuka kemungkinan negotiable, tapi tetap saja lelaki mereka pandang sebagai penentu negosiasi. ${ }^{10}$ Sementara sebagian yang lain lebih memilih terjebak idealisasi bahwa

\footnotetext{
${ }^{10}$ Untuk menunjuk, seperti TGH Muharrar Mahfuzh, TGH Muhammad Zainul Majdi, dan TGH Mustiadi Abhar. Namun, mereka tetap bergeming dalam menghayati "keutamaan" lelaki. Dalam
} 
perempuan seyogyanya di rumah (sektor domestik) dan lelaki berkiprah di luar (sektor publik). ${ }^{11}$ Secara tersirat pemungkinan negosiasi itu membuka kans demokratisasi dalam proses-proses relasional lelaki dengan perempuan (misal dalam hubungan suami-isteri), tapi idealisasi peran dikotomik secara substantif mengarah pada menguatnya keyakinan bahwa pilahan peran itu given dan taken for granted (takdir, kodrat). Artinya, pilihan perempuan (isteri) untuk aktif di ranah publik, misalnya untuk mencari nafkah, serta-merta mempersyaratkan kondisi yang betul-betul darurat (misalnya, si suami sakit-sakitan, tak lagi mampu menulang-punggungi kebutuhan keluarga).

Dalam pada itu, penafsiran ulama tempo dulu cenderung tertransfer relatif utuh dalam benak tuan guru. Bisa dikatakan tak ada persepsi yang mencoba beranjak secara serius dari anasir pemikiran Islam klasik. Relatif tak ada yang betul-betul genuine-alih-alih mengharap munculnya persepsi yang tampil sebagai counter-discourse bagi wacana masa lalu itu. Kecenderungan copying itu terlihat terutama ketika mereka mempersepsi tentang pembagian peran publikdomestik yang mereka tumpukan pada argumen "superioritas lelaki atas perempuan". ${ }^{12}$ Akibatnya, mereka cenderung bersimpul seragam bahwa posisi lelaki atas perempuan adalah superior, dan karena itu lelaki atau suami otomatis berstatus pemimpin keluarga. Dalam hal ini, para informan mengekor mayoritas mufassir klasik yang melansir dua alasan untuk memperkuat argumen bahwa

hal keinginan perempuan (isteri) untuk berkiprah di sektor publik, misalnya, tetap tergantung pada adanya ijin lelaki (suami).

${ }^{11}$ Satu-dua informan bahkan melarang keras perempuan keluar rumah karena ke-qath $\hat{\imath}$-an pilahan peran itu, seperti dipersepsikan TGH Lalu Muhamad Turmuzi Badarudin. Bahkan lebih jauh, TGH Najmuddin Ma'mun, memandang fakta kian banyaknya perempuan keluar rumah mencari nafkah (seperti TKW) dan lelaki di rumah sebagai tanda-tanda akhir zaman (kiamat).

${ }^{12}$ Argumentasi tersebut lazimnya didasarkan pada Qs.al-Nisâ (4): 34. Ayat lain yang acap dijadikan sandaran, antara lain, adalah Qs.al-Nisâ (4): 11 tentang pola bagi waris 2:1, Qs.alBaqarah (2): 228 tentang tingkatan lebih suami daripada isteri, dan Qs.al-Baqarah (2): 282 tentang nilai kesaksian dua orang perempuan setara dengan satu lelaki. 
lelaki memanglah qawwâmûn atas perempuan, yakni: (1)karena Allah telah melebihkan sebagian mereka (lelaki) atas sebagian yang lain (perempuan), dan (2)karena mereka (lelaki) telah memberi nafkah dari sebagian hartanya.

Dari sudut perspektif gender, dari sanalah problem mengedepan. Terlebih menyadari kenyataan fenomenal betapa penafsiran "tak sadar gender" dari tuan guru itu, sebagaimana juga khazanah tafsir klasik, ternyata melebar memasuki wilayah sosial-politik. Implikasi dari melebarnya lingkup tafsiran Qs. al-Nisâ' (4): 34 itu serius. Betapa tidak, praktis hampir seluruh tafsiran para ulama klasik, sebagaimana diamini para informan, itu membuntu jalan bagi perempuan untuk memasuki ranah sosial-politik dan membangun eksistensi di sana.

Soal kemungkinan perempuan memegang kepemimpinan sosial-politik, secara teologis-normatif para tuan guru cenderung kompak menolak, minimal keberatan. Alasan yang diajukan kebanyakan berkutat di hal-hal klasik. Dan klise, seperti rendahnya kualitas akal perempuan, ketidaksetaraan nilai kesaksian mereka dengan lelaki, dan semacamnya. Selain menggunakan (penafsiran atas) ayat-ayat tertentu (semisal Qs. al-Nisâ' [4]: 34) untuk menghadang perempuan ke gray area itu juga diperkukuh dengan beberapa hadits. ${ }^{13}$ Beberapa bahkan menopangnya dengan menunjuk ketiadaan preseden sejarah di masa awal Islam. ${ }^{14}$ Sementara itu, hanya sedikit informan yang persepsinya cenderung apologetis. ${ }^{15}$ Terutama dalam

\footnotetext{
${ }^{13}$ Yang paling lazim adalah hadits "lan yufliha qawmun wallaw amrahum imra'atan"; dan "alnisâ' nâqishâtun 'aqlin wa dînin". Kedua hadits termaksud dalam wacana gender paling kerap disebut sebagai salah dua contoh di antara sekian hadits "misoginis".

${ }^{14}$ Seperti diungkap TGH Musthafa Umar bahwa Nabi tak pernah melibatkan perempuan sebagai pengampu urusan-urusan politik, padahal kala itu ada beberapa perempuan cerdas semisal sayyidah 'Aisyah ra. Nyaris senafas TGH Turmuzi Badarudin. "Dalam Islam tidak boleh, tidak ada ayat atau hadits (baca: preseden sejarah, pen.) yang membolehkannya...," tegasnya.

${ }^{15}$ Misalnya, TGH Muharrar Mahfuzh. Simak tuturnya: "Taruhlah pada porsi al-rijâl ra'in 'alâ bayt ahlih, al-mar'ah ra'iyat fî bayt zawjihâ... Ada pembagian kepemimpinan di sini. Kepemimpinan global yang lebih luas dan harus ke sana ke mari Allah berikan kepada laki-laki. Perempuan
} 
hal klaim asumtif bahwa peran terbaik perempuan adalah menjadi ibu; mengambil peran di luar rumah merupakan hal negatif bagi diri dan kepribadiannya, keluarga, dan lingkungan sekitarnya.

Sementara itu, soal nilai kesaksian perempuan juga amat sering dianggap sebagai salah satu pembenaran teologis tentang kurangnya akal perempuan. Sandaran yang acap diajukan adalah Qs. al-Baqarah (2): 282, juga hadits Nabi saw, "nuqshân 'aql wa dîn”. Paling-sedikit berdasar keduanya, pandangan bahwa perempuan bernilai setengah dari laki-laki dan kurang akal mengakar kuat di benak sebagai besar umat Islam, tak terkecuali para informan.

Dalam fiqh, wacana kesaksian perempuan dan lelaki umumnya juga merujuk pada ayat tersebut. Secara eksplisit-tekstual memang digariskan bahwa nilai kesaksian seorang lelaki itu sebanding dengan kesaksian dua orang perempuan. Namun, sebenarnya, ayat itu secara khusus hanya ditujukan pada hal-hal yang berkaitan dengan kontrak keuangan, soal mu'amalah. Tidak ada ketentuan untuk hal-hal lain, misalnya ke urusan kesaksian di soal jinâyah. Akan tetapi, ironisnya, dari ayat tersebut para ahli fiqh, yang kemudian diamini oleh ulama belakangan seperti tuan guru (informan), menarik suatu aturan umum untuk berbagai masalah, baik keungan maupun di luarnya, bahwa satu saksi laki-laki setara dengan dua saksi perempuan. Praktis, bukannya menyikapinya sebagai ayat kontekstual, para tuan guru, seperti pula kebanyakan ulama klasik, memperlakukannya justru sebagai ayat normatif. Akibatnya, konteks kehadiran ayat tersebut di mana sektor bisnis kala itu adalah dunia yang dimonopoli lelaki sedang perempuan tidak berpengalaman praktis terabaikan.

pemimpin juga, tapi lebih dikaitkan dengan tugas-tugas sebagai ibu rumah-tangga. Di situlah dia sebagai pemimpin..." 
Bentuk lain dari bukti tersubordinasinya perempuan dalam wacana fiqh terdapat dalam kasus pola pembagian waris antara lelaki dan perempuan yang tak sebanding. Perempuan mendapat separuh dari bagian yang diperoleh laki-laki. Ketentuan itu memang diderivasi secara tekstual dari Qs. al-Nisâ' (4): 11. Oleh para ulama, ayat tersebut dikategorikan qath 'î. Keberlakuannya absolut dan tak boleh dibantah. Dan itu pula yang diikuti para tuan guru sebagaimana menampak dalam persepsi mereka.

Reasoning yang lazim dikedepankan dari pembagian semacam itu adalah karena lelaki memerlukan harta untuk memenuhi kebutuhan diri dan menafkahi isteri serta anak-anaknya, sedang perempuan hanya membutuhkan biaya untuk dirinya sendiri dan bila menikah keperluannya ditanggung sang suami. Jadi wajar bila perempuan mendapat satu (setengah) bagian saja. Begitulah alasan yang paling sering diusung-sebagaimana juga dilakukan para informan-untuk menjustifikasi kebenaran tekstual dari ayat tersebut.

Sementara dalam fiqh munakahah, salah satu persoalan yang hingga kini masih menjadi bahan diskusi ramai dan pelik adalah soal poligami. Pelik, terutama bagi perempuan. Islam sendiri, "gara-gara" pesan tekstual tentang “pembolehan poligami” pada Qs. al-Nisâ' (4): 3 itu, kerap dikecam sebagai antidemokrasi dan HAM dalam kehidupan suami-isteri di mana poligami dilihat sebagai salah satu bentuk diskriminasi dan marginalisasi terhadap kaum perempuan.

Pada umumnya, dalam membincang soal poligami, hampir semua kitab fiqh menyoroti sisi kebolehan (mubâhah)-nya saja, tanpa mengkritisi kembali hakikat di balik kebolehan tersebut, baik secara historis, sosiologis, maupun antropologis. 
Dalam pada itu, kalangan fuqahâ' justru menepikan aspek terpenting dari wacana poligami, yakni 'adâlah (keadilan). Gaya penglihatan serupa juga dilakuan oleh rata-rata tuan guru.

Ajaran Islam memang membolehkan laki-laki mengawini empat perempuan sekaligus, tapi hanya jika ia mampu berbuat adil. Kalau tidak, maka terlarang. Fain khiftum allâ ta'dilû fawâhidatan, demikian Allah mewanti-wanti di ujung ayat "kesukaan" kaum lelaki itu. Menariknya, di situ Allah menggunakan term 'adâlah, bukan qisthun. Tekanannya tentu adalah keadilan kualitatif yang hakiki, semisal perasaan cinta, kasih, dan rasa sayang, yang tak bisa diukur secara matematis. Sementara konseptualisasi 'keadilan' dalam wacana poligami oleh para fuqahâ' umumnya cenderung dimaknai kuantitatif. Terukur, misalnya keadilan dalam menjatah giliran hari dan pemerataan nafkah. Mereka abai terhadap aspek-aspek keadilan kualitatif. Soal-soal psikologis-kualitatif seperti itu relatif tak tersentuh oleh para fâqih, juga tuan guru.

Sejauh ini, ada yang terasa hilang memang dalam wacana fiqh tentang poligami, terutama ketika perbincangan hanya memfokus pada kebolehannya beserta segala rasionalisasi di baliknya. Model penafsiran monolitik memang sangat sering ditunjukkan para ulama klasik dalam wacana fiqh. Hingga tingkat tertentu, gaya itu pula yang diikuti para informan. Itu terkait karena saking kuatnya kuasa wacan yang membentuk persepsi mereka—seperti diulas di muka.

Dari tilikan berperspektif gender, dapat diringkas bahwa persepsi para tuan guru (informan) secara umum bias, diskriminatif, dan tidak sadar gender. Ironisnya, dalam masyarakat religius dan tradisional, seperti Sasak di Lombok, hal itu rentan memicu problem. Lantaran bersandar pada logika keagamaan, maka 
dengan segera itu akan dianggap sebagai kebenaran atau pengetahuan final-terlebih di tengah sikap tanpa reserve masyarakat terkait tingkat pendidikan mereka yang umumnya rendah.

\section{b.3. Menimbang Prospek}

Bagaimana bila persepsi gender sedemikian dibawa ke dalam konteks pemberdayaan perempuan di Lombok? Menilik konstruk epistemologis dari persepsi gender para tuan guru di atas, ke depan prospek pemberdayaan perempuan di pulau "seribu masjid" itu agaknya bakal tak cukup cerah mengingat pemegang kontrol atas wacana "misoginis" itu adalah mereka. Betapa tidak, dalam masyarakat yang berstruktur budaya tradisional-paternalistik, posisi mereka sangatlah determinan dalam tiap proses perubahan sosial. Segala apa yang dihela tuan guru ke publik dengan segera akan dijadikan pedoman berpikir dan berprilaku masyarakat. Maka dapat dibayangkan apa yang akan mewarnai kesadaran gender masyarakat bila wacana yang diyakini dan dikembangkan tuan guru sebagai kebenaran adalah wacana yang "membenci" perempuan.

Pra-anggapan itu didasarkan sekurangnya pada dua hal yang saling berkelindan, yaitu struktur sosial-budaya masyarakat Sasak yang tradisionalpaternalistik dan peran tuan guru yang karenanya sangat menentukan setiap geraknafas perubahan sosial (termasuk diskursus sosial gender) di Lombok. Melalui dua hal tersebut, wacana keagamaan "misoginis" yang direproduksi terus-menerus oleh tuan guru bukan mustahil bakal semakin memperkuat mentalitas agraris ${ }^{16}$

\footnotetext{
${ }^{16}$ Dalam masyarakat agraris, terutama yang berpola pertanian menetap dan mengembangkan tanaman intensif (pola umum sistem pertanian masyarakat Sasak), kaum perempuan umumnya tersisih dari peran-peran produktif. Lelakilah yang mengendalikan produksi, sedang perempuan menjalankan fungsi-fungsi kerumahtanggaan. Muncullah apa yang dikenal sebagai "lingkungan publik-domestik" (domestic-public sphere), lihat Louise Lamphere, "The Domestic Sphere of Women and the Public World of Man: The Strenghts and Limitations of an Antropological
} 
masyarakat Sasak. Probabilitasnya dapat dirunut dari pembentukan kesadaran gender masyarakat Sasak sendiri. Bagi masyarakat Sasak yang religius, alas dasar kesadaran itu adalah keyakinan-keyakinan derivat dari ajaran agama. Prosesproses produksi dan transmisi pengetahuan keagamaan dalam banyak hal amatlah ditentukan oleh signifikansi peran para ulama, tuan guru. "Persoalan" agaknya bermula dari situ.

Dalam konteks dinamika sosial masyarakat Sasak, tuan guru hadir tidak hanya memainkan peran sebagai "makelar budaya" (cultural broker), ${ }^{17}$ tetapi lebih jauh juga berperan sebagai kreator aktif bagi perubahan sosial, yakni memperkenalkan anasir sistem luar dan menggerakkan perubahan dalam masyarakat. ${ }^{18}$ Sebagai makelar budaya, tuan guru berupaya mengaitkan dunia kecil pesantren atau komunitasnya atau dirinya dengan dunia di luarnya. ${ }^{19}$ Mereka mengawasi (juga melangsungkan) proses parochialization atas nilai-nilai universal yang merambahi dunia kecilnya dan melakukan universalisasi atas nilai-nilai lokal ke dunia luar. ${ }^{20}$ Sementara sebagai aktor kreatif dari dinamika sosial, para tuan guru secara relatif efektif menjadi figur panutan atau patron masyarakat. Untuk hal

Dictionary," dalam Gender in Cross-Cultural Perspective, eds. Caroline B. Brettel dan Carolyn F. Sargent, New Jersey: Prentice Hall, 1993, 67-75; atau pola "dikotomi luar-dalam" (inside-outside dichotomy), lihat selengkapnya, M. Kay Martin dan Barbara Voorhies, Female of the Species, New York: Columbia University, 1975. Dikotomi publik dan domestik itu pada gilirannya melahirkan ideologi gender yang mengacungkan superioritas "alamiah" lelaki di atas inferioritas "alamiah" perempuan. Pola relasi gendernya ditandai dengan ciri-ciri masyarakat patriarkhis, memberi peranan lebih besar pada lelaki. Lihat Stephen K. Sanderson, Sosiologi Makro: Sebuah Pendekatan terhadap Realitas Sosial, terj. Farid Wajidi dan S. Meno, Jakarta: Rajawali press, 1993, 402-3, 407-8.

${ }^{17}$ Istilah ini diintrodusir oleh Eric Wolf dan digunakan oleh Clifford Geertz sebagai konsep utama dalam "The Javanese Kijaji: The Changing Role of a Cultural Broker," Comparative Studies on Society and History, II/2, January, 1960, 229. Relevansi peminjaman ini didasarkan atas fakta adanya persamaan dalam beberapa hal antara "kyai" di Jawa (subjek penelitian Geertz) dan "tuan guru" di Lombok, yakni mereka berada dalam masyarakat yang sama berkultur tradisional.

${ }^{18}$ Bdk. Horiko Horikoshi, Kyai dan Perubahan Sosial, Jakarta: P3M, 1987, 242.

${ }^{19}$ Lihat Geertz, "The Javanese," 229.

${ }^{20}$ Ibid., 228. 
terakhir ini, mereka benar-benar tampil sebagai penentu cetak-biru (blue-print) wacana keagamaan di Lombok.

Melalui hubungan patron-klien itu, para tuan guru menikmati cukup banyak "privilege sosial" yang termiliki lantaran kapasitas intelektual keagamaan atau latar sosial-ekonomi-politik mereka. ${ }^{21}$ Boleh jadi sistem sosial masyarakat Sasak hari ini telah mengalami banyak pergeseran dan perubahan diferensiasi fungsional. Peran-peran mediasi sosial tuan guru selama ini mulai banyak diwakili (diambil-alih!) oleh beragam mediasi institusional yang marak bermunculan seiring dinamika cepat dunia modern. Namun, tetap saja, dalam derajat tertentu, para tuan guru masih memiliki privilege sosial. Sebab, bagaimanapun, hingga kini secara de facto masyarakat Sasak masih menaruh kepercayaan besar pada mereka. Dengan "hak-hak istimewa" selaku elite agama itu, mereka bahkan masih dapat mengambil peran, hingga tingkat tertentu, sebagai "pressure group", bahkan "rulling class", dalam keseluruhan struktur sosial masyarakat. ${ }^{22}$ Dapatlah dibayangkan kemudian betapa besar impact eksistensi mereka di tengah dinamika sosial masyarakat Sasak.

Melihat besarnya impact yang dapat ditimbulkan, peran tuan guru tentu saja sangat strategis dan signifikan bagi persebaran "virus" wacana gender ke tengah masyarakat. Namun, jika yang dikembangkan justru wacana misoginis, maka sangat mungkin justru menjadi penghambat utama. Sebagaimana dimaklumkan, para informan terpilih bukanlah tuan guru "kecil-kecilan", bukan "kacangan".

\footnotetext{
${ }^{21}$ Tanpa adanya "keunggulan kompetitif" itu, secara politis, kehadiran mereka tidak legitimate di hadapan umatnya. Dalam masyarakat paternalistik, legitimasi (sosial) itu penting, menjadi syarat pra-kondisi berhasil-tidaknya mereka dalam menjalankan peran sebagai agen perubahan sosial. $B d k$., dengan tesis Geertz tentang keagenan "kyai Jawa" (subjek penelitiannya). Ibid., 228-49.

${ }^{22}$ Lihat teoretisasinya pada M. Munandar Soelaiman, Dinamika Masyarakat Transisi: Mencari Alternatif Teori Sosiologi dan Arah Perubahan, Jogjakarta: Pustaka Pelajar, 1998, 148.
} 
Semuanya, dalam batasnya masing-masing, berstatus "kelas berat". Dalam realitas Lombok mutakhir, para informan terpilih itu adalah para tuan guru yang berpengaruh dan umumnya memang bermassa besar dengan fanatisme yang meluap-luap. Mereka berbasis dan/atau mengasuh pesantren, institusi pendidikan yang dalam banyak hal masih berada dalam pusaran ortodoksi (salaf). Untuk konteks Lombok (NTB), pesantren-pesantren para informan itu terbilang besar-menjadi jujugan santri dari daerah-daerah lain di NTB. Terlebih dari sisi usia, beberapa informan terkategori sepuh, yang minimal lantaran senioritasnya itu mereka dituakan di kalangan tuan guru sendiri, apalagi oleh masyarakat. Itulah mengapa peran mereka bernilai strategis dalam upaya pemberdayaan perempuan. Atau sebaliknya, justru kontra-produktif-memperkukuh status quo realitas ketertindasan perempuan melalui pelanggengan cara-pandang keagamaan yang bias gender.

Sejauh melihat persepsi tuan guru, agaknya fenomena terakhirlah yang paling mungkin menjadi kenyataan. Pembesaran kesadaran keagamaan tersebut ke wilayah publik, secara langsung maupun tidak, bakal mendukung struktur sosial patriarkhis-androsentris yang didominasi lelaki. Tak ayal, keterpinggiran perempuan, terkhusus di ruang publik, akan terus menyesaki realitas keseharian masyarakat Sasak. Suram, begitulah kira-kira prospek pemberdayaan perempuan di Lombok ke depan. Maka adalah penting dan mendesak menghadirkan secara tanpa henti wacana gender emansipatoris tidak hanya sebagai wacana tanding (counter discourse), atau apalagi cuma wacana alternatif (alternative discourse), tetapi lebih jauh musti diarahkan kepada pemunculannya sebagai sungguhsungguh counter-culture, suatu entitas budaya tanding. 


\section{Kesimpulan}

Dari hasil penelitian diatas, maka dapat digaris bawahi bahwa pelibatan tuan guru dalam setiap program peningkatan kesadaran gender adalah niscaya. Lewat itu pula dapat diidentifikasi anasir progresif-transformatif di antara mereka yang mungkin dapat dijadikan mitra potensial selama proses-proses transisional ke arah penciptaan sensitifitas gender di masyarakat. Pelibatan itu penting untuk membantu menjelaskan dengan bahasa yang dimengerti umatnya tentang urgensi sensitifitas gender. Ini juga dalam rangka memanfaatkan otoritas keilmuan dan privilege sosial mereka demi melegitimasi ide dan ikhtiar penyadaran gender di tengah masyarakat sekaligus penguatan agenda-agenda gender mainstreaming (pengarusutamaan gender) di level struktur.

Hal krusial lain yang perlu dibidik dalam rangka revitalisasi kesadaran gender adalah sektor pendidikan. Terutama institusi pendidikan pesantren di mana tuan guru menjadi sentral dari hampir seluruh proses pendidikan di dalamnya. Upaya itu sepatutnya dilakukan sedari dini-dari pendidikan tingkat terdasar. Dimulai dengan mereformasi kurikulum pendidikan, redesigning silabus, hingga ke penerbitan buku-buku ajar (muatan lokal) yang sensitif gender, dan seterusnya.

Melalui upaya sinergis dan penciptaan suatu aliansi strategis dengan melibatkan tuan guru, proses-proses penyadaran dan peningkatan sensitifitas gender bukan lagi hal sulit. Melalui "tangan-tangan barokah" mereka yang peka gender itulah harapan akan terciptanya suatu tatanan masyarakat Sasak yang berkeadilan gender, yang memanusiakan perempuan, rasanya tak berlebihan. Muaranya adalah berlangsungnya perubahan fundamental pada cara pikir 
masyarakat demi terciptanya apa yang secara "utopis" diangankan kaum feminis, suatu "masyarakat tanpa ketimpangan gender" (genderless society).

Tanpa itu, secara langsung maupun tidak, kita akan jumpai sisi ironis dari realitas faktual agama. Di genggaman tuan guru (para ulama) yang tak sensitif gender, agama-lewat tafsir atasnya yang kemudian dianggap sebagai agama itu sendiri-bakal kerap tampil sebagai salah satu kendala utama bagi upaya pembalikan struktur ketidakadilan gender, terkhusus di level kesadaran kulturkeagamaan masyarakat. Dus, sebuah adagium masyhur akan menemukan pembenar: betapa mudah bagi perempuan untuk selalu menjadi sahabat bagi agama, tetapi sebaliknya agama tak selalu mampu menjadi sahabat bagi perempuan

Suatu penafsiran atau hasil pemahaman atas al-Qur'an dan al-Sunnah, siapapun pelakunya, termasuk ulama (tuan guru), seyogyanya memang tidak dibiarkan menjadi alat religius guna menghalang-halangi perempuan untuk merumuskan sendiri kemanusiaannya dan membangun eksistensinya. Sebaliknya, ia harus memberikan pencerahan harapan di kini dan masa depan. Itulah mengapa harus betul-betul disadari bahwa syari'ah pada dasarnya bersifat situasional. Ia senantiasa berkembang dinamis sebagai respons terhadap berbagai tantangan yang dihadapi masyarakat (umat Islam). Dengan lain kata, ia bukanlah entitas transendental, dan karenanya harus diterapkan secara kreatif-bukan malah dibelenggu—dalam kondisi yang terus berubah agar jargon "congkak" al-Islâm shâlih li kulli zamân wa makân tetap punya relevansi sosialnya. Bukankah itu adalah tugas utama tuan guru, para ulama, sang waratsat al-anbiyấ? 


\section{BIBLIOGRAFI}

al-Bukhârî, Imâm, "Kitâb al-Haidl - Bâb Tark al-Haa'idl al-Shaum," dalam Shahîh al-Bukhârî, Juz I, Hadits ke-298, Beirut: Dâr Ibn Katsir al-Yamâmah, t.th.

Arkoun, Mohammed, "Logocentrisme et Vérité Religieuse dans la Pensée Islamique," dalam Studia Islamica, 35,1972.

Engineer, Asghar Ali, Hak-hak Perempuan dalam Islam, terj. Farid Wajidi dan Cici Farkha Assegaf, Jogjakarta: LSPAA-Yayasan Prakarsa, 1994.

Gadamer, Hans Georg, Truth and Method, London, Sheed and Ward, 1975.

Geertz, Clifford, "The Javanese Kijaji: The Changing Role of a Cultural Broker," Comparative Studies on Society and History, II/2, January, 1960.

Horikoshi, Horiko, Kyai dan Perubahan Sosial, Jakarta, P3M, 1987.

King, Richard, Agama, Orientalisme, dan Poskolonialisme, terj. Agung Prihantoro Jogjakarta, Qalam, 2001.

Kress, Gunther, "Critical Discourse Analysis," dalam Annual Review of Applied Linguistics, no. 11, 1991.

Lamphere,Louise, "The Domestic Sphere of Women and the Public World of Man: The Strenghts and Limitations of an Antropological Dictionary," dalam Gender in Cross-Cultural Perspective, eds. Caroline B. Brettel dan Carolyn F. Sargent, New Jersey: Prentice Hall, 1993, 67-75.

Mas'udi, Masdar F, Islam dan Hak-hak Reproduksi Perempuan, Bandung, Mizan, 1997

Muslim, Imâm, "Kitâb al-Îmân - Bâb Nuqshân al-Îmân bi Naqsh al-Tha'at," dalam Shahîh Muslim, Juz I, Hadits ke-132, Beirut: Dâr al-Fikr, 1992.

Martin, M. Kay dan Voorhies, Barbara, Female of the Species, New York, Columbia University, 1975.

Palmer, Richard E, Hermeneutics: Interpretation Theory in Schleiermacher, Dilthey, Heidegger, and Gadamer, Evanston, Northwestern University Press, 1969.

Rahmat, Jalaluddin, "Dari Psikologi Androsentris ke Psikologi Feminis: Membongkar Mitos-mitos tentang Perempuan," Jurnal Ulumul Qur'an, Edisi Khusus, V/5\&6, 1994: 12-28. 
Soelaiman, M. Munandar, Dinamika Masyarakat Transisi: Mencari Alternatif Teori Sosiologi dan Arah Perubahan, Jogjakarta, Pustaka Pelajar, 1998.

, Nalar Islami dan Nalar Modern: Berbagai Tantangan dan Jalan Baru, ab. Rahayu S. Hidayat, Jakarta: INIS, 1994.

Sanderson, Stephen K, Sosiologi Makro: Sebuah Pendekatan terhadap Realitas Sosial, terj. Farid Wajidi dan S. Meno, Jakarta, Rajawali press, 1993.

Senge, Peter M, The Fifth Discipline: The Art and Practice of the Learning Organization, New York, Doubleday Currency, 1990.

Umar,Nasaruddin, "Perspektif Gender dalam Islam," Jurnal Paramadina, I/1, Juli-Desember, 1998,

Van Dijk, Teun Adrianus, "Editor's Forward to Critical Discourse Analysis," dalam Discourse and Society, vol. 4, no. 2, 1993.

--------, "Principles of Critical Discourse Analysis," dalam Discourse and Society, vol. 4, no. 2,1993. 